\title{
Evaluation of Some Adjuvants in Improving Foliar Fertilizers Efficiency
}

\author{
Dina M Omran, Ahmed A Ibrahim* Manal M Mubarak, Mona I Nossier \\ Soils and Water Dept, Fac of Agric, Ain Shams Univ, P.O. Box 68, Hadayek Shoubra 11241, Cairo, Egypt \\ * Corresponding author: ahmed_abdelfatah@agr.asu.esu.eg \\ DOI:10.21608/ajs.2021.95510.1416
}

Received 20 September, 2021 ; Accepted 7 December, 2021

\section{Keywords:}

Adjuvants, Improved foliar fertilizers, Surfactant, Static surface tension, Static contact angle

\begin{abstract}
A series of lab and field experiments were carried out to evaluate the possibility of using some substances as adjuvants added to the foliar fertilizer tank to improve fertilizer application and use efficiency. Each of the suggested substances was prepared in 10 concentrations treatments, ranging between 0.05 and $2 \mathrm{~g} / \mathrm{L}$. The effect of each concentration on static surface tension and static contact angle in liquid/air/glass and solid plant leaves/air interface were used to evaluate and find out the optimum concentration of each substance to be used as adjuvant. An Adjmix-D1 was prepared using $0.6 \mathrm{~g} / \mathrm{L}$ Triethanolamine and $0.6 \mathrm{~g} / \mathrm{L}$ liquid soap as surfactants, $0.6 \mathrm{~g} / \mathrm{L}$ glycerin as a humectant, $0.6 \mathrm{~g} / \mathrm{L}$ Arabic gum as a sticker and $0.6 \mathrm{~g} / \mathrm{L}$ urea as a penetrator. The obtained results showed that fruit yield as well as $\mathrm{N}, \mathrm{K}, \mathrm{Fe}, \mathrm{Zn}$ and $\mathrm{Mn}$ contents in white eggplants and cucumber leaves are positively increased by the applications of improved foliar fertilizers (IFF). This increase can be arranged in the following descending order: Adjmix-D1 > Adjmix-D2 $>$ Liquid soap > Rixi film > Triethanolamine. It could be concluded that the Adjmix-D1 can be used as an effective adjuvant for improving foliar fertilizer application efficiency.
\end{abstract}

\section{Introduction}

Several methods were recently used in delivering nutrients for plants including soil and foliar methods. Foliar nutrition is considered as one of the most common methods, which is used to deliver the needed nutrients to plants in adequate concentrations and improve plant nutritional status as well as increase the crop yield and its quality (Smolen 2012). The fertilizer management is very important due to its role in plant growth and development beside its biochemistry as well as in controlling plant diseases (Dordas 2009).

The applied nutrients can enter the leaves through many steps by penetrating the cuticle or entering through the stomata before entering the plant cell where they are used in metabolism (Oosterhuis and Weir 2010).
The main dilemma of foliar nutrients application is that the waxy cuticle, covering the surfaces of all plant foliage, as an effective barrier to the penetration of exogenous chemicals into the underlying tissues (Martin and Juniper 1970). Thus, it is apparent that many of the principles of formulation employed with foliarapplied systemic pesticides also may be used to advantage for foliar fertilizer application (Price 1982). The most common way of improving the interaction of spray droplets and plant leaf surface is by modify the surface tension of the droplet. Congreve (2019) mentioned that droplets with a high surface tension bounce off target surfaces, while those with a low surface tension tend to spread on contact and retained.

The ability of foliar sprays to stick to leaves is essential to enable uptake of nutrients. Many plant species showed to have low wettability due to leaf surface roughness, which caused, by waxes and hairs 
(De Ruiter et al 1995). To overcome these issues, adjuvants including surfactant to improved leaf wetting, Sticker to minimize fertilizer wash off and Humectant to prolong the time of nutrients absorption are often added to spray tank (Fernández and Eichert 2009). A large number of adjuvants are commercially available for use in combination with agrochemicals, however their effectiveness with foliar applied fertilizers is often unknown (De Assuncao et al 2019).

It has been also suggested to use a surfactant as an adjuvant for improving wetting properties of foliar fertilizer on leaves (i.e., low surface tension and low contact angle), which might increase the rate of uptake of foliar-applied fertilizers (Fernández and Eichert 2009). It follows that poorer wetting (higher surface tension and contact angles) will result in lower uptake rates of the nutrients from different fertilizer formulations. Even though addition of an adjuvant will increase the surface area of the sprayed solution, there seems to be an optimal concentration for both economic and effective coverage (Rasmussen 2016).

In fact, effective spray applications are required to help in reducing the operational costs with adequate spraying coverage for large acreage operations. By adding adjuvants to the spray solution, the droplet dispersion on leaf surfaces as well as the surface area of the droplets might increase, creating larger coverage area per volume. This larger surface area can also increase the evaporation speed of the solution through the heat exchange between the environment and the plant, but the plant will have a greater opportunity to absorb the solution before evaporation (Ortiz et al 2007).

The main purpose of this investigation is to evaluate the ability of some selected substances to act as adjuvants (that improve the performance of foliar fertilizers) can be added to foliar fertilizer tank (six-laboratory grade and two commercial) in order to improve nutrients use efficiency by plants. The subsequent short-term uptake of foliar applied $\mathrm{N}, \mathrm{K}, \mathrm{Fe}, \mathrm{Zn}$ and $\mathrm{Mn}$ as a reflection of foliar fertilizer use efficiency are taken under consideration.

\section{Materials and Methods}

A series of lab and field experiments were carried out to evaluate the possibility of using some substances as adjuvants added to the foliar fertilizer tank for improving foliar fertilizers application and use efficiency.

\subsection{Suggested substances as adjuvants}

The suggested adjuvants included Triethanolamine (TEA), liquid soap (prepared by mixing 7 parts of cotton seed oil with 1 part of $\mathrm{KOH}$ and 10 parts of $\mathrm{H}_{2} \mathrm{O}$ ) as surfactants, glycerin as a humectant, Arabic gum, molasses as stickers and urea as a penetrator. Citric acid used to adjust the $\mathrm{pH}$ of the final foliar fertilizer solution to about seven. Camina red food color is also used in $0.1 \mathrm{~g} / \mathrm{L}$ to make the spray solution clearer in vision. Rixi film (25\% Sodium laurele ether sulfate) is used as a commercial adjuvant for comparison. Each of the suggested substance was prepared in 10 concentrations treatments, i.e., $0.05,0.1,0.2,0.4,0.6,0.8,1$, $1.25,1.5$, and $2 \mathrm{~g} / \mathrm{L}$. The effect of each concentration on static surface tension (SST) and static contact angle (SCA) in liquid/air/glass and solid plant leaf/air interface were used to evaluate and find out the optimum concentration of each substance to be used as an adjuvant which had the highest effects on reducing SST and SCA.

The optimum concentrations of the suggested six substances mixed each alone or in combination with the final foliar fertilizer solution tank in addition to the $\mathrm{pH}$ adjuster and color were all determined. The commercial adjuvant (Rixi film) and pure water were also used by mixing each alone with the final foliar fertilizer solution tank as control treatments without any other additives. The SST was determined at room temperature using drop weight method as described by Soni (2019) and by using capillary tube method described by Harkins and Brown (2019). The SCA was measured using a smart cellphone as described by Lamour and El-Hamraoui (2010). The SCA measurements were made on the adaxial (top) side of leaves taken at vegetative stage of white eggplants and cucumber plants as varied in their leaf surface roughness.

\subsection{Field experiments using improved foliar ferti- lizers}

Two field trails were conducted on clay loam soils at Aboelnaga, Basos, Qaluobia Governorate at the location of $\left(30^{\circ} 07^{\prime} 48.6^{\prime \prime} \mathrm{N}, 31^{\circ} 13^{\prime} 40.5^{\prime \prime} \mathrm{E}\right)$ for cucumber and in Elmanawat, Aboelnomros, Giza Governorate at the location of $\left(29.9^{\circ} 17.1^{\prime} 95.0^{\prime \prime} \mathrm{N}, 31.2^{\circ}\right.$ 45.7' 75.0" E) for white eggplants. Crops in these locations were irrigated by surface flooding irrigation system using fresh water delivered from River Nile (EC is about $0.43 \mathrm{dS} / \mathrm{m}$ ). All field experiments were designed and statistically analyzed in complete randomized block design. 
Un-improved foliar fertilizer (UIFF) alone or in combination with the suggested adjuvants treatments were used for improving foliar fertilizer (IFF) in addition to control treatments either Rixi film and pure water were sprayed weekly for 4 times in sequence applications on the test plants using low pressure sprayer. The first applications of IFF or UIFF and control treatments were beginning just before fruiting stages of each crop. No negative interaction was observed between any of the suggested adjuvants with foliar fertilizers.

Crop types, cultivars, dates of Planting, dates of the applications of foliar fertilizer treatments and age of plants at each crop harvesting or leaves sampling are presented in Table 1. Chemicals used for preparing the stock solutions of the different foliar fertilizer's formula (K1, K1.5, K2 and K3) are shown in Table 2. Nutrient contents in the final foliar fertilizers solutions at using two $\mathrm{cm}^{3} / 1$ from the stock solutions are presented in Table 3.

To evaluate the effects of the IFF on nutrients use efficiency, foliage plant samples were collected after one week from each application of the improved and UIFF. The collected plant foliage was prepared for chemical analyses to determine $\mathrm{N}, \mathrm{K}, \mathrm{Fe}, \mathrm{Zn}, \mathrm{Mn}$ contents using methods described by Benton (2001).

\section{Results and Discussion}

\subsection{Effects of the suggested adjuvants on static surface tension}

Results in Table 4 indicated that the lowest values of SST determined by drop weight method were $45.4,19.7,48.2,50.1,49.3$ and $51.0 \mathrm{~N} / \mathrm{m}$ at $33^{\circ} \mathrm{C}$ for TEA, liquid soap, glycerin, Arabic gum, molasses and urea. These lowest values of surface tension taken at the concentrations of 0.6, 1.0, 0.6, $1.0,0.8$ and $0.8 \mathrm{~g} / \mathrm{L}$ respectively. The lowest value of surface tension for the commercial adjuvants (Rixi film) was $28.8 \mathrm{~N} / \mathrm{m}$ at the concentrations of $0.4 \mathrm{~g} / \mathrm{L}$ respectively. SST value of pure water determined under similar conditions was $74.7 \mathrm{~N} / \mathrm{m}$ at $33^{\circ} \mathrm{C}$.

These results are in agreement with that of $\mathrm{Tu}$ and Randall (2003) who mentioned that surfactants are the most widely used products of the chemical industry and probably the most important group of all adjuvants for foliar application. However, the most common types of activa- tor adjuvants are surfactants (Penner 2000) such as TEA, liquid soap. Due to the special structure of surfactants, their presence at the surface is more beneficial, and therefore the surface tension can be efficiently reduced (Rosen and Kunjappu 1989). The term 'surfactant' derived from 'surface active agent' and should not be mixed-up with the term 'adjuvant' since adjuvants are not limited to surfactants (Penner 2000).

Data in Table 5 show the effects of the different suggested adjuvants concentrations on the average values of SST determined by drop weight method and capillary tube methods in $\mathrm{N} / \mathrm{m}$. Results indicated that the lowest values of SST were determined by capillary tube method were 43.1, 20.4, 41.0, 37.5, 27.4 and 60.2 $\mathrm{N} / \mathrm{m}$ at $25^{\circ} \mathrm{C}$ for TEA, liquid soap, glycerin, Arabic gum, molasses and urea respectively.

These lowest values of SST were taken at the concentrations of $0.6,0.8,0.6,0.8,0.8$ and $0.8 \mathrm{~g} / \mathrm{L}$ respectively. The lowest value of SST for the commercial adjuvant (Rixi film) was $15.9 \mathrm{~N} / \mathrm{m}$ at the concentration of $0.6 \mathrm{~g} / \mathrm{L}$. SST value of pure water was $72.3 \mathrm{~N} / \mathrm{m}$ at $25^{\circ} \mathrm{C}$. It worthy to mentioned that the SST value determined by drop weight method at $33^{\circ} \mathrm{C}$ was higher than that determined by capillary tube method at $25^{\circ} \mathrm{C}$ by about $12.6 \%$. In spite this difference, similar trends observed for the effect of adjuvant treatments on SST values particularly the concentrations of each adjuvant at the lowest values of SST. This result agrees with that of Park et al (1999) who found a linear relationship between SST and temperature. Where, similar trend with very little differences observed between SST values determined by drop weight method (Table 4) and capillary tube method (Table 5). The average of both values to represent the effects of different suggested adjuvants for improving foliar fertilizer on its SST values was taken under consideration. Therefore, it observed that the average lowest SST values taken at concentrations of $0.6,0.8,0.6,0.8,0.8,0.8$, and $0.6 \mathrm{~g} / \mathrm{L}$ for TEA, liquid soap, glycerin, Arabic gum, molasses, urea and Rixi film. The corresponding average values obtained for SST were 43.1, 20.4, 41.0, $37.5,27.4,60.2$ and $15.9 \mathrm{~N} / \mathrm{m}$ respectively. The average value of SST for pure water was $73.5 \mathrm{~N} / \mathrm{m}$. These results are in agreement with that observed by Chen et al (2018).

The high SST values of urea, glycerin, Arabic gum and molasses even at the lowest SST values comparing with that of the tested commercial adjuvant (Rixifilm) was expected. The reason could be that not all these tested adjuvants acted as surfactants for increasing fluid spreading rate but act as a penetrator, humectant, and sticker respectively. However, these differences may be attributed to the unknown components of such commercial adjuvants which may contains 
Table 1. Crop types and cultivars, planting date, date of foliar fertilizer treatments applications, date of fruit crop harvesting, and the foliar fertilizer (FF) formula used

\begin{tabular}{|c|c|c|c|c|c|c|}
\hline \multirow{2}{*}{$\begin{array}{c}\text { Crop types } \\
\text { and cultivar }\end{array}$} & \multirow{2}{*}{$\begin{array}{c}\text { Planting } \\
\text { dates }\end{array}$} & \multirow{2}{*}{$\begin{array}{c}\text { Beginning date } \\
\text { of the } \mathbf{1}^{\text {St }} \text { Spray of }\end{array}$} & \multicolumn{4}{|c|}{ Sampling time, dates and plant ages } \\
\cline { 4 - 7 } & & $\mathbf{F F}$ & $\mathbf{1}$ & $\mathbf{2}$ & $\mathbf{3}$ & $\mathbf{4}$ \\
\hline White eggplants & $5-3-2020$ & $14-5-20$ at & $21-5-20$ & $28-5-20$ & $4-6-20$ & $11-6-20$ \\
Apastra CV. & & 70 days old & 77 days & 84 days & 91 days & 98 days \\
& & FF formula & $*$ K2 & K3 & K3 & K3 \\
\hline Cucumber & $26-8-2020$ & $4-10-20$ at & $11-10-20$ & $18-10-20$ & $25-10-20$ & $1-11-20$ \\
Hayel CV. & & 59 days old & 46 days & 53 days & 60 days & 67 \\
& & FF formula & K1.5 & K2 & K3 & K3 \\
\hline
\end{tabular}

* $\mathrm{K} 1.5, \mathrm{~K} 2$ and $\mathrm{K} 3$ are $\mathrm{K}_{2} \mathrm{O}: \mathrm{N}$ ratios in FF's, i.e. 1:1, 1:1.5, 1:2 and 1:3 respectively

Table 2. Chemicals used for preparing the stock solutions of the different used foliar fertilizers formulae

\begin{tabular}{|c|c|c|c|c|c|c|c|c|c|c|c|c|}
\hline \multirow{2}{*}{$\begin{array}{c}\text { Foliar Fert's } \\
\text { formulae }\end{array}$} & $\mathbf{A N}$ & $\mathbf{K N}$ & MgS & FS & $\mathbf{Z S}$ & MS & $\mathbf{N}$ & $\mathrm{K}_{2} \mathrm{O}$ & MgO & $\mathbf{F e}$ & Zn & Mn \\
\hline & \multicolumn{6}{|c|}{$\mathrm{g} / \mathrm{L}$ in stock foliar fertilizer solutions } & \multicolumn{6}{|c|}{$\mathrm{g} / \mathrm{L}$ in stock foliar fertilizer solutions } \\
\hline K1.5 & 2.9 & 4.3 & 0.6 & 1.9 & 0.9 & 0.9 & 10.0 & 18.8 & 7.20 & 2.06 & 0.95 & 1.04 \\
\hline $\mathrm{K} 2$ & 2.6 & 5.2 & 0.5 & 1.8 & 0.9 & 0.9 & 6.81 & 22.7 & 6.52 & 2.00 & 0.95 & 1.06 \\
\hline K3 & 2.0 & 5.9 & 0.4 & 1.8 & 0.9 & 0.9 & 1.79 & 25.6 & 4.91 & 1.99 & 0.89 & 1.00 \\
\hline
\end{tabular}

AN: Ammonium nitrate $(33 \% \mathrm{~N}), \mathrm{KN}$ : Potassium nitrate $\left(13 \% \mathrm{~N}, 46 \% \mathrm{~K}_{2} \mathrm{O}\right), \mathrm{MgS}$ : Magnesium sulfate $(16.8 \% \mathrm{MgO})$, FS: Iron sulfate $(18.2 \mathrm{Fe}), \mathrm{ZS}$ : Zinc sulfate $(19.9 \% \mathrm{Zn})$, MS: manganese sulfate $(17.7 \% \mathrm{Mn})$.

Table 3. Nutrient contents in the final foliar fertilizers solutions

\begin{tabular}{|c|c|c|c|c|c|c|c|}
\hline \multirow[b]{2}{*}{$\begin{array}{l}\text { Foliar Fert's } \\
\text { formulae }\end{array}$} & \multirow[b]{2}{*}{ N/K2O/MgO/Fe/Zn/Mn Ratios } & $\mathbf{N}$ & $\mathrm{K}_{2} \mathrm{O}$ & MgO & $\mathbf{F e}$ & $\mathbf{Z n}$ & Mn \\
\hline & & \multicolumn{6}{|c|}{$\begin{array}{l}\text { Nutrient concentrations in the final FF solutions } \\
\text { using } 2 \mathrm{~cm}^{3} / \mathrm{L}\end{array}$} \\
\hline $\mathrm{K} 1.5$ & $1 / 1.5 / 0.2 / 0.1 / 0.05 / 0.05$ & 58 & 86 & 11.5 & 3.7 & 1.9 & 1.8 \\
\hline $\mathrm{K} 2$ & $1 / 2 / 0.2 / 0.1 / 0.05 / 0.05$ & 52 & 104 & 10.4 & 3.6 & 1.9 & 1.9 \\
\hline K3 & $1 / 3 / 0.2 / 0.1 / 0.05 / 0.05$ & 39 & 118 & 7.8 & 3.6 & 1.8 & 1.8 \\
\hline
\end{tabular}

Table 4. Effects of the different adjuvant concentrations suggested for improving foliar fertilizer on SST determined by drop weight method at $33^{\circ} \mathrm{C}$ in $\mathrm{kg} / \mathrm{S}^{2}$.

\begin{tabular}{|c|c|c|c|c|c|c|c|c|}
\hline \multirow{2}{*}{$\begin{array}{l}\text { Adjuvant } \\
\text { Conc. g/L } \\
\end{array}$} & \multicolumn{7}{|c|}{ Adjuvants suggested for improving foliar fertilizers } & \multirow{2}{*}{$\begin{array}{c}\text { SST at } \\
33^{\circ} \mathrm{C}\end{array}$} \\
\hline & TEA & Liquid soap & Glycerin & Arabic gum & Molasses & Urea & Rixi film & \\
\hline Pure water & 74.7 & 74.7 & 74.7 & 74.7 & 74.7 & 74.7 & 74.7 & 74.7 \\
\hline 0.05 & 56.6 & 41.1 & 53.0 & 54.5 & 52.0 & 57.0 & 57.1 & 53.2 \\
\hline 0.1 & 46.1 & 40.9 & 52.1 & 56.4 & 50.4 & 54.8 & 55.2 & 50.2 \\
\hline 0.2 & 45.7 & 42.5 & 48.5 & 50.5 & 52.0 & 53.4 & 47.1 & 47.5 \\
\hline 0.4 & 47.3 & 28.7 & 48.5 & 50.7 & 52.4 & 54.2 & 28.8 & 43.3 \\
\hline 0.6 & 45.4 & 24.0 & 48.2 & 50.8 & 52.4 & 54.7 & 29.2 & 42.3 \\
\hline 0.8 & 47.6 & 21.6 & 48.2 & 51.1 & 49.3 & 51.0 & 29.3 & 41.5 \\
\hline 1.0 & 46.6 & 19.7 & 49.0 & 50.1 & 55.8 & 53.6 & 29.3 & 42.4 \\
\hline 1.25 & 46.2 & 19.9 & 49.0 & 50.4 & 55.4 & 53.3 & 28.9 & 42.1 \\
\hline 1.5 & 45.9 & 19.8 & 49.6 & 50.5 & 57.8 & 54.0 & 29.7 & 42.7 \\
\hline 2.0 & 45.6 & 20.0 & 50.6 & 50.3 & 54.1 & 53.6 & 29.4 & 42.2 \\
\hline Mean & 47.3 & 27.8 & 49.7 & 51.5 & 53.2 & 53.9 & 36.4 & 44.7 \\
\hline
\end{tabular}


Table 5. Effects of the different adjuvant concentrations suggested for improving foliar fertilizer on SST determined by capillary tube method at $25^{\circ} \mathrm{C}$ in $\mathrm{N} / \mathrm{m}$

\begin{tabular}{|c|c|c|c|c|c|c|c|c|}
\hline \multirow{2}{*}{$\begin{array}{c}\text { Adjuvant } \\
\text { Conc. g/L }\end{array}$} & \multicolumn{9}{|c|}{ Adjuvants suggested for improving foliar fertilizers } & SST at \\
\cline { 2 - 9 } & TEA & Liquid soap & Glycerin & Arabic gum & Molasses & Urea & Rixi film & $\mathbf{2 5}{ }^{\circ}$ C \\
\hline Pure water & 72.3 & 72.3 & 72.3 & 72.3 & 72.3 & 72.3 & 72.3 & 72.3 \\
\hline 0.05 & 48.8 & 40.3 & 54.4 & 51.0 & 53.3 & 61.8 & 23.8 & 44.7 \\
\hline 0.10 & 48.8 & 40.8 & 48.8 & 51.1 & 57.9 & 69.8 & 21.5 & 44.9 \\
\hline 0.20 & 46.5 & 40.0 & 43.1 & 40.8 & 40.9 & 69.2 & 20.4 & 40.6 \\
\hline 0.40 & 47.7 & 30.6 & 43.1 & 46.0 & 40.9 & 66.4 & 20.4 & 39.0 \\
\hline 0.60 & 43.1 & 22.1 & 41.0 & 40.8 & 34.1 & 64.8 & 15.9 & 35.1 \\
\hline 0.80 & 49.4 & 20.4 & 52.3 & 37.5 & 27.4 & 60.2 & 17.0 & 35.9 \\
\hline 1.00 & 49.4 & 20.4 & 47.8 & 47.8 & 34.1 & 69.4 & 17.0 & 38.0 \\
\hline 1.25 & 49.4 & 20.4 & 43.3 & 42.7 & 36.5 & 68.8 & 17.0 & 37.0 \\
\hline 1.50 & 51.1 & 21.1 & 43.2 & 41.0 & 38.8 & 69.5 & 18.2 & 38.3 \\
\hline 2.00 & 54.6 & 22.1 & 43.3 & 39.3 & 41.2 & 65.6 & 17.0 & 37.7 \\
\hline Mean & 48.9 & 27.8 & 46.0 & 43.8 & 40.5 & 66.5 & 18.8 & 39.1 \\
\hline
\end{tabular}

several surfactants acting together in reducing SST and in consequently increasing spreading rate of fluids on solid surfaces.

In general, all the suggested adjuvants can used to improve foliar fertilizers has lower SST values comparing with that of pure water (Prado et al 2016). The calculated net reduction in SST of the tested adjuvants comparing with that of pure water were about 42, 62, 45, 35, 27, 12.1 for TEA, liquid soap, glycerin, Arabic gum, molasses and urea respectively. The net reduction in SST more pronounced for liquid soap than the other adjuvants or even the commercial adjuvants under investigation.

\subsection{Effects of the suggested adjuvants on static contact angle}

The SCA measurements made on the adaxial (top) side of leaves taken at vegetative stage of white eggplants and cucumber plants varied in leaf surface roughness. Results presented in Table 6 revealed that the lowest SCA values at air/glass interface were observed at concentrations of 0.4 , $0.4,0.6,0.4,0.4,0.6$ and $0.4 \mathrm{~g} / \mathrm{L}$ for TEA, liquid soap, glycerin, Arabic gum, molasses, urea and Rixi film, respectively. The corresponding values of contact angle were 15.0, 14.8, 15.8, 14.3, 15.1, 17.3 and $15.7^{\circ}$ at $25^{\circ} \mathrm{C}$ in the same order.

The lowest SCA values for Air/eggplant leaf interface were $20.6,16.9,14.2,22.1,18.9,23.4$ and $13.6^{\circ}$ at concentrations of $0.4,0.6,0.6,0.4$, $0.8, \quad 0.6$ and $0.4 \mathrm{~g} / \mathrm{L}$ respectively, and for Air/cucumber leaf interface were 22.8, 15.7, 27.6, $25.9,19.7,23.2$ and $14.3^{\circ}$ at concentrations of 0.8 , $0.8,0.8,0.6,0.6,0.8$ and $0.6 \mathrm{~g} / \mathrm{L}$ for cucumber using TEA, liquid soap, glycerin, Arabic gum, molasses, urea and Rixi film respectively. These results are in agreement with that obtained by Santos et al (2019).

It could be concluded that the efficiency of adjuvant concentration in reducing SCA and in consequently increase spreading rate of foliar fertilizers sprayed on plant foliage are more pronounced for white eggplants than for cucumber. This is a fact even for the commercial adjuvant under investigation (Rixifilm).

This may ascribed to the high roughness of cucumber leaves comparing with that of white eggplants. Nairn et al (2013) reported that despite no standardized method for quantifying leaf surface roughness has yet been established, it is well known that surface roughness is a dominant factor in spray droplet adhesion. However, droplet spreading generally decreases with increasing leaf roughness (Gaskin et al 2005). Hence, the ability of foliar sprays to stick to leaves is essential to enable uptake of nutrients. Many plant species including wheat have been shown to have low wettability due to leaf surface roughness which caused by waxes and hairs (De Ruiter et al 1995).

Data in Table 7 summarized the highly effective adjuvants concentrations in reducing SST and SCA under different conditions taken from Tables 4, 5 and 6. These concentrations used to prepare adjuvants mixtures for improving the efficiency of foliar fertilizers.

According to the average of the effective adjuvant's concentrations shown in Table 7 , two adjuvant mixture were prepared to consist of some adjuvants act as surfactant, humectant, sticker and penetrator as follow: Adjmix-D1 contains $0.6 \mathrm{~g} / \mathrm{L}$ TEA and $0.6 \mathrm{~g} / \mathrm{L}$ liquid soap as surfactants, $0.6 \mathrm{~g} / \mathrm{L}$ glycerin as a humectant, $0.6 \mathrm{~g} / \mathrm{L}$ Arabic gum as a sticker and $0.6 \mathrm{~g} / \mathrm{L}$ urea 
Table 6. Effects of different adjuvant suggested for improving foliar fertilizers on contact angle of adjuvant and glass, white eggplants, and cucumber leaf interface

\begin{tabular}{|c|c|c|c|c|c|c|c|}
\hline \multirow{3}{*}{$\begin{array}{c}\text { Adjuvant } \\
\text { Concentrations } \\
\text { g/L }\end{array}$} & \multicolumn{7}{|c|}{ Adjuvant treatments } \\
\hline & TEA & Liquid soap & Glycerin & Arabic gum & Molasses & Urea & Rixifilm \\
\hline & \multicolumn{7}{|c|}{ Contact angle Air/glass interface in degree $\left(^{\circ}\right)$} \\
\hline 0.05 & 16.4 & 25.7 & 17.4 & 17.4 & 16.9 & 28.2 & 16.1 \\
\hline 0.1 & 15.9 & 25.7 & 18.0 & 15.1 & 15.6 & 25.4 & 17.2 \\
\hline 0.2 & 15.7 & 23.6 & 18.9 & 18.5 & 18.4 & 24.6 & 20.9 \\
\hline 0.4 & 15.0 & 14.8 & 17.5 & 14.3 & 15.1 & 26.1 & 15.7 \\
\hline 0.6 & 15.0 & 15.3 & 15.8 & 16.8 & 16.6 & 17.3 & 16.1 \\
\hline 0.8 & 19.1 & 16.8 & 16.6 & 17.9 & 15.4 & 21.5 & 22.9 \\
\hline 1.0 & 18.5 & 17.0 & 18.4 & 19.2 & 18.2 & 21.1 & 16.8 \\
\hline 1.25 & 16.0 & 18.8 & 21.8 & 18.0 & 16.1 & 25.7 & 16.8 \\
\hline 1.5 & 17.6 & 23.8 & 17.2 & 19.4 & 15.5 & 22.5 & 23.5 \\
\hline \multirow[t]{2}{*}{2.0} & 19.1 & 15.3 & 16.1 & 18.2 & 16.0 & 29.7 & 20.2 \\
\hline & \multicolumn{7}{|c|}{ Contact angle of Air/Eggplant leaf interface in degree $\left(^{\circ}\right)$} \\
\hline 0.05 & 27.4 & 31.1 & 23.8 & 31.6 & 24.4 & 23.9 & 24.1 \\
\hline 0.1 & 27.3 & 32.3 & 21.0 & 26.2 & 30.6 & 27.7 & 22.4 \\
\hline 0.2 & 25.1 & 25.6 & 29.8 & 22.9 & 32.1 & 30.5 & 23.5 \\
\hline 0.4 & 20.6 & 24.1 & 15.5 & 22.1 & 30.5 & 28.0 & 13.6 \\
\hline 0.6 & 21.8 & 16.9 & 14.2 & 24.7 & 23.9 & 23.4 & 15.8 \\
\hline 0.8 & 26.7 & 23.4 & 14.6 & 28.1 & 18.9 & 27.1 & 17.1 \\
\hline 1.0 & 25.9 & 31.2 & 15.7 & 27.6 & 20.1 & 29.9 & 19.0 \\
\hline 1.25 & 23.5 & 20.7 & 19.3 & 33.7 & 24.7 & 23.8 & 16.1 \\
\hline 1.5 & 28.1 & 24.2 & 20.7 & 24.1 & 25.7 & 23.7 & 15.3 \\
\hline \multirow[t]{2}{*}{2.0} & 25.0 & 31.3 & 21.4 & 26.7 & 24.6 & 25.4 & 15.5 \\
\hline & \multicolumn{7}{|c|}{ Contact angle of Air/Cucumber leaf interface in degree $\left(^{\circ}\right)$} \\
\hline 0.05 & 32.3 & 35.7 & 30.1 & 32.7 & 29.1 & 20.5 & 30.2 \\
\hline 0.1 & 32.1 & 25.8 & 29.6 & 32.1 & 26.9 & 31.0 & 25.1 \\
\hline 0.2 & 27.3 & 21.7 & 33.5 & 30.5 & 22.8 & 28.1 & 25.2 \\
\hline 0.4 & 25.5 & 19.7 & 28.4 & 27.7 & 22.2 & 24.8 & 22.3 \\
\hline 0.6 & 26.6 & 17.9 & 28.1 & 25.9 & 19.7 & 25.7 & 14.3 \\
\hline 0.8 & 22.8 & 15.7 & 27.6 & 27.0 & 21.2 & 23.2 & 25.1 \\
\hline 1.0 & 27.0 & 17.9 & 31.3 & 26.8 & 24.6 & 23.3 & 25.2 \\
\hline 1.25 & 29.9 & 17.8 & 30.2 & 35.0 & 20.1 & 25.3 & 18.8 \\
\hline 1.5 & 32.6 & 17.2 & 29.5 & 31.9 & 22.8 & 27.4 & 22.2 \\
\hline 2.0 & 26.7 & 16.7 & 27.8 & 29.5 & 23.9 & 30.3 & 26.1 \\
\hline
\end{tabular}

Table 7. Summary of the highly effective adjuvants concentrations in reducing SST and SCA under different conditions

\begin{tabular}{|c|c|c|c|c|c|c|c|}
\hline \multirow{2}{*}{ Treatments } & \multicolumn{7}{|c|}{ Adjuvant treatments } \\
\cline { 2 - 8 } & TEA & Liquid soap & Glycerin & Arabic gum & Molasses & Urea & Rixifilm \\
\cline { 2 - 8 } & \multicolumn{7}{|c|}{ Effective adjuvants concentrations in reducing of SST and contact angle - g/L } \\
\hline ST at $33^{\circ} \mathrm{C}$ & 0.6 & 1.0 & 0.6 & 1.0 & 0.8 & 0.8 & 0.4 \\
\hline ST at $25^{\circ} \mathrm{C}$ & 0.6 & 0.8 & 0.6 & 0.8 & 0.8 & 0.8 & 0.6 \\
\hline $\mathrm{CA}_{\text {Air/Glass }}$ & 0.4 & 0.4 & 0.4 & 0.4 & 0.4 & 0.6 & 0.4 \\
\hline $\mathrm{CA}_{\text {Air/Eggplant }}$ & 0.4 & 0.6 & 0.6 & 0.4 & 0.8 & 0.6 & 0.4 \\
\hline $\mathrm{CA}_{\text {Air/Cucumber }}$ & 0.8 & 0.8 & 0.8 & 0.6 & 0.6 & 0.8 & 0.6 \\
\hline Mean & 0.56 & 0.72 & 0.60 & 0.64 & 0.68 & 0.72 & 0.48 \\
\hline & \multicolumn{7}{|c|}{ The suggested adjuvant mixtures suggested to use for improving foliar fertilizers - g/L } \\
\hline Adjmix-D1 & 0.6 & 0.6 & 0.6 & 0.6 & -- & 0.6 & -- \\
\hline Adjmix-D2 & 0.6 & 0.6 & 0.6 & -- & 0.6 & 0.6 & - \\
\hline
\end{tabular}


as a penetrator in addition to Adjmix-D2 contains $0.6 \mathrm{~g} / \mathrm{L} \mathrm{TEA}$ and $0.6 \mathrm{~g} / \mathrm{L}$ liquid soap as surfactants, $0.6 \mathrm{~g} / \mathrm{L}$ glycerin as a humectant, $0.6 \mathrm{~g} / \mathrm{L}$ Molasses as a sticker and $0.6 \mathrm{~g} / \mathrm{L}$ urea as a penetrator.

To evaluate the efficiency of using the suggested adjuvants each alone or in combination as Adjmix-D1 and Adjmix-D2 for improving foliar fertilizers, a series of field experiments were carried out by spraying some vegetable crops weekly for 3 to 4 sequence applications. The tested plants sprayed with the tested adjuvants each alone or in combination as Adjmix-D1 or Adjmix-D2 with its optimum concentration to evaluate its efficiency on nutrients contents and crop yield.

\subsection{Effects of the improved foliar fertilizers (IFF) on some nutrient's contents}

White eggplants plants sprayed with foliar fertilizers improved by mixing with the recommended concentrations of the suggested adjuvants each alone or in combinations as Adjmix-D1 and Adjmix-D2. Concerning the changes in nutrients contents in white eggplant leaves at the different sampling periods along to growth stage. The effects of the tested adjuvants used for improving foliar fertilizers each alone or in combination (Adjmix-D1 and Adjmix-D2) added in four sequence applications on some nutrient contents in white eggplants and cucumber leaves and its relative effects to that of the first date of sampling $=100$ is presented in Tables 8 and 9, respectively.

Data in Table 8 show some nutrient contents in white eggplants leaves as affected by IFF in four sequences applications relative to that of the first date of harvesting (i.e., 21-5-2020) equal 100.

Results revealed that the increases in the relative $\mathrm{N}$ and $\mathrm{K}$ contents in eggplant leaves during the four sequence foliar fertilizer applications ranged between 111 and 114\% for $\mathrm{N}$ and 106 and $124 \%$ for K. Similar increases also observed for $\mathrm{Fe}, \mathrm{Zn}$ and $\mathrm{Mn}$ contents in white eggplant leaves as affected by the improved foliar fertilizer (IFF) as shown in Table 8. These increases ranged between 109 and $117 \%$ for Fe, 107 and $126 \%$ for $\mathrm{Zn}$ and 113 and $128 \%$ for Mn relative to the first sampling equal 100 .

Data in Table 9 show some nutrient contents in cucumber leaves as affected by IFF in four sequences applications relative to that of the first date of harvesting (11-10-2020) equal 100. Results revealed that the increases in the relative $\mathrm{N}$ and $\mathrm{K}$ contents in cucumber leaves during the four sequence foliar fertilizer applications ranged between $103-111 \%$ for N and $108-111 \%$ for K. Similar results also observed for $\mathrm{Fe}, \mathrm{Zn}$ and $\mathrm{Mn}$ contents in white eggplant leaves as affected by the IFF as shown in Table 9. The increases in $\mathrm{Fe}, \mathrm{Zn}$ and $\mathrm{Mn}$ contents in white eggplant leaves ranged between 115 and $140 \%$ for $\mathrm{Fe}, 116$ and $127 \%$ for $\mathrm{Zn}$ and 125 and $132 \%$ for Mn relative to the first sampling equal 100 .

It observed the increases in $\mathrm{N}, \mathrm{K}, \mathrm{Fe}, \mathrm{Zn}$ and $\mathrm{Mn}$ contents in cucumber leaves as affected by the application of the IFF more pronounced than that in white eggplants. These increases in $\mathrm{N}, \mathrm{K}, \mathrm{Fe}, \mathrm{Zn}$ and $\mathrm{Mn}$ contents in cucumber leaves may be attributed to the positive effect of the high degree of roughness of cucumber leaves on reducing the losses of the nutrients content added in foliar fertilization by slipping. This leads to an increase in the efficiency of plant utilization of the foliar fertilizer content (De Ruiter et al 1995).

Data summarized in Table $\mathbf{1 0}$ show some nutrient contents in white eggplants and cucumber leaves as affected by different adjuvant treatments used for improving foliar fertilizer and relative values to that of $\mathrm{UIFF}=100$. Nitrogen content in white eggplant leaves increased by the applications of IFF to about 124, 120, 115 and $115 \%$ for Adjmix-D1, Adjmix-D2, liquid soap and Rixifilm, respectively, relative to UIFF = 100.

Nitrogen content in cucumber leaves increased by improving foliar fertilizers using TEA, liquid soap, urea, Rixifilm, Adjmix-D1 and Adjmix-D2 to about 4.42 (118\%), 4.1 (109), 4.45 (119), 4.11 (111), 4.45 (119) and $3.89 \%(104 \%)$, respectively, relative to $\mathrm{UIFF}=100$.

Results revealed in Table $\mathbf{1 0}$ showed that the highest values and relative increase in $\mathrm{K}$ content in white eggplant leaves were 4.60 (119), 4.58 (119), 4.54 (117), 4.52 (117) and 4.45\% (115\%) for Adjmix-D1, Rixifilm, liquid soap, Adjmix-D2 and TEA, respectively comparing with that of UIFF which was $3.56 \%$ $(100 \%)$, respectively. Similar increases were also obtained for K content in cucumber leaves as affected by the application of different adjuvants each alone or in combination for improving foliar fertilizer. These increases reached to about 3.64 (110), 3.78 (114), 3.57 (108), 3.86 (117), 3.95 (120) and $3.63 \%$ (110\%), respectively relative to $\mathrm{UIFF}=100$.

Regarding the effects of the tested substances, either alone or in combination used as adjuvants for improving foliar fertilizer on some micronutrient's contents in white eggplant and cucumber leaves, results in Table $\mathbf{1 0}$ indicated similar positive effects particularly for Adjmix-D1, Adjmix-D2, Rixifilm, 
Table 8. Nutrient contents in white eggplants leaves as affected by different adjuvant treatments used for improving foliar fertilizer in four sequence applications

\begin{tabular}{|c|c|c|c|c|c|c|c|c|c|c|}
\hline \multirow{3}{*}{$\begin{array}{l}\text { Adjuvant } \\
\text { treatments }\end{array}$} & $\mathbf{N}$ & $\mathbf{K}$ & $\mathbf{F e}$ & $\mathbf{Z n}$ & Mn & $\mathbf{N}$ & $\mathbf{K}$ & $\mathbf{F e}$ & $\mathbf{Z n}$ & Mn \\
\hline & \multicolumn{2}{|c|}{$\%$} & \multicolumn{3}{|c|}{ ppm } & \multicolumn{2}{|c|}{$\%$} & \multicolumn{3}{|c|}{ ppm } \\
\hline & \multicolumn{5}{|c|}{ Sampled date: (1) 21-5-2020 } & \multicolumn{5}{|c|}{ Sampled date: (2) 28-5-2020 } \\
\hline Pure water & 4.03 & 3.02 & 115 & 25.4 & 143 & 4.19 & 4.08 & 110 & 27.8 & 145 \\
\hline UIFF & 4.31 & 3.63 & 122 & 31.7 & 178 & 4.21 & 4.14 & 123 & 32.1 & 173 \\
\hline TEA & 4.55 & 4.43 & 135 & 36.5 & 201 & 4.85 & 4.39 & 143 & 35.7 & 195 \\
\hline Liquid soap & 4.84 & 4.54 & 133 & 35.3 & 195 & 4.90 & 4.42 & 144 & 36.6 & 196 \\
\hline Glycerin & 4.39 & 4.29 & 137 & 33.7 & 187 & 4.76 & 4.34 & 137 & 32.5 & 190 \\
\hline Arabic gum & 4.57 & 4.39 & 131 & 33.8 & 191 & 4.72 & 4.38 & 137 & 32.4 & 189 \\
\hline Molasses & 4.45 & 4.32 & 132 & 32.0 & 175 & 4.46 & 4.18 & 128 & 27.4 & 183 \\
\hline Urea & 4.59 & 4.28 & 131 & 31.5 & 174 & 4.63 & 4.37 & 137 & 31.6 & 189 \\
\hline Rixi film & 4.56 & 4.68 & 136 & 36.9 & 203 & 4.86 & 4.37 & 142 & 37.3 & 202 \\
\hline Adjmix-D1 & 5.65 & 4.72 & 138 & 38.5 & 227 & 5.02 & 4.54 & 148 & 38.9 & 214 \\
\hline Adjmix-D2 & 5.54 & 4.64 & 131 & 36.4 & 224 & 4.83 & 4.33 & 147 & 36.8 & 207 \\
\hline Mean-IFF & 4.82 & 4.50 & 134 & 35.4 & 200 & 4.78 & 4.37 & 140 & 34.4 & 196 \\
\hline Relative to UIFF & 112 & 124 & 110 & 112 & 113 & 114 & 106 & 114 & 107 & 113 \\
\hline Relative to P. water & 120 & 149 & 116 & 140 & 140 & 114 & 107 & 127 & 124 & 135 \\
\hline \multirow{2}{*}{$\mathrm{LSD}_{0.05}$} & 0.25 & 0.9 & 13.0 & 3.3 & 17.0 & 0.6 & 0.19 & 19.0 & 3.6 & 23.0 \\
\hline & \multicolumn{5}{|c|}{ Sampled date: (3) 4-6-2020 } & \multicolumn{5}{|c|}{ Sampled date: (4) 11-6-2020 } \\
\hline Pure water & 4.18 & 3.66 & 113 & 25.8 & 136 & 4.10 & 3.67 & 105 & 23.9 & 141 \\
\hline UIFF & 4.32 & 3.75 & 119 & 29.6 & 154 & 4.35 & 3.94 & 120 & 27.9 & 150 \\
\hline TEA & 4.89 & 4.23 & 126 & 38.7 & 195 & 4.68 & 4.76 & 141 & 38.2 & 197 \\
\hline Liquid soap & 4.90 & 4.37 & 136 & 39.0 & 205 & 5.17 & 4.83 & 147 & 39.2 & 202 \\
\hline Glycerin & 4.71 & 4.11 & 120 & 30.0 & 183 & 4.73 & 4.63 & 127 & 33.3 & 193 \\
\hline Arabic gum & 4.65 & 4.26 & 127 & 33.2 & 186 & 4.64 & 4.48 & 133 & 34.2 & 178 \\
\hline Molasses & 4.36 & 4.17 & 125 & 32.4 & 179 & 4.65 & 4.25 & 123 & 27.4 & 172 \\
\hline Urea & 4.57 & 4.34 & 123 & 33.5 & 170 & 4.66 & 4.42 & 135 & 33.6 & 191 \\
\hline Rixi film & 5.05 & 4.62 & 134 & 38.6 & 195 & 5.24 & 4.65 & 148 & 36.8 & 202 \\
\hline Adjmix-D1 & 5.08 & 4.63 & 140 & 40.7 & 207 & 5.52 & 4.86 & 159 & 38.4 & 203 \\
\hline Adjmix-D2 & 5.03 & 4.46 & 138 & 39.6 & 204 & 5.25 & 4.67 & 146 & 36.5 & 198 \\
\hline Mean-IFF & 4.80 & 4.35 & 130 & 36.2 & 192 & 4.95 & 4.62 & 140 & 35.3 & 193 \\
\hline Relative to UIFF & 111 & 116 & 109 & 122 & 124 & 114 & 117 & 117 & 126 & 128 \\
\hline Relative to P. water & 115 & 119 & 115 & 140 & 140 & 121 & 126 & 133 & 148 & 137 \\
\hline $\mathrm{LSD}_{0.05}$ & 0.57 & 0.55 & 15.0 & 9.0 & 40.0 & 080 & 0.70 & 26.0 & 8.5 & 43.0 \\
\hline
\end{tabular}


Table 9. Nutrient contents in cucumber leaves as affected by different adjuvant treatments used for improving foliar fertilizer in four sequence applications

\begin{tabular}{|c|c|c|c|c|c|c|c|c|c|c|}
\hline \multirow{3}{*}{$\begin{array}{l}\text { Adjuvant } \\
\text { treatments }\end{array}$} & $\mathbf{N}$ & $\mathbf{K}$ & $\mathbf{F e}$ & Zn & Mn & $\mathbf{N}$ & $\mathbf{K}$ & $\mathbf{F e}$ & Zn & Mn \\
\hline & \multicolumn{2}{|c|}{$\%$} & \multicolumn{3}{|c|}{ ppm } & \multicolumn{2}{|c|}{$\%$} & \multicolumn{3}{|c|}{ ppm } \\
\hline & \multicolumn{5}{|c|}{ Sampled date: (1) 11-10-2020 } & \multicolumn{5}{|c|}{ Sampled date: (2) 18-10-2020 } \\
\hline Pure water & 2.90 & 2.86 & 41.6 & 26.7 & 54.3 & 3.02 & 2.68 & 46.7 & 26.9 & 52.8 \\
\hline UIFF & 3.50 & 3.10 & 49.8 & 37.8 & 61.2 & 3.64 & 3.04 & 53.1 & 30.6 & 60.3 \\
\hline TEA & 4.20 & 3.48 & 69.8 & 49.0 & 84.3 & 4.81 & 3.13 & 71.9 & 40.4 & 87.9 \\
\hline Liquid soap & 4.11 & 3.40 & 72.9 & 50.1 & 82.2 & 3.97 & 3.45 & 78.6 & 42.5 & 88.1 \\
\hline Glycerin & 3.64 & 3.55 & 60.0 & 38.1 & 71.6 & 3.78 & 3.45 & 57.9 & 41.2 & 73.7 \\
\hline Arabic gum & 3.73 & 3.42 & 54.2 & 43.1 & 77.4 & 3.73 & 3.13 & 52.7 & 39.7 & 76.5 \\
\hline Molasses & 3.45 & 3.24 & 52.1 & 40.1 & 69.9 & 3.97 & 3.26 & 44.7 & 35.3 & 69.9 \\
\hline Urea & 4.34 & 3.15 & 61.6 & 36.1 & 71.3 & 3.78 & 3.44 & 39.0 & 24.2 & 71.3 \\
\hline Rixi film & 3.78 & 3.49 & 74.9 & 46.1 & 86.5 & 4.01 & 3.49 & 76.2 & 45.9 & 81.3 \\
\hline Adjmix-D1 & 4.11 & 3.40 & 71.9 & 55.8 & 80.9 & 4.53 & 3.71 & 74.3 & 45.7 & 83.1 \\
\hline Adjmix-D2 & 3.55 & 3.14 & 65.4 & 38.2 & 75.9 & 3.83 & 3.29 & 71.7 & 42.4 & 82.0 \\
\hline Mean-IFF & 3.89 & 3.35 & 63.5 & 43.8 & 76.7 & 4.05 & 3.36 & 61.3 & 38.9 & 79.1 \\
\hline Relative to UIFF & 111 & 108 & 127 & 116 & 125 & 111 & 111 & 115 & 127 & 131 \\
\hline Relative to P. water & 134 & 117 & 153 & 164 & 141 & 134 & 125 & 131 & 145 & 150 \\
\hline \multirow[t]{2}{*}{$\mathrm{LSD}_{0.05}$} & 0.6 & 0.3 & 22.0 & 12.0 & 19.0 & 0.19 & 0.40 & 21.0 & 11.5 & 18.0 \\
\hline & \multicolumn{5}{|c|}{ Sampled date: (3) 25-10-2020 } & \multicolumn{5}{|c|}{ Sampled date: (4) 1-11-2020 } \\
\hline Pure water & 3.96 & 3.07 & 44.5 & 27.2 & 53.4 & 3.33 & 3.20 & 45.3 & 29.1 & 51.4 \\
\hline UIFF & 3.92 & 3.51 & 53.6 & 34.5 & 60.9 & 3.92 & 3.56 & 54.8 & 37.6 & 63.9 \\
\hline TEA & 4.20 & 3.87 & 81.5 & 44.4 & 88.6 & 4.48 & 4.08 & 83.2 & 49.3 & 90.5 \\
\hline Liquid soap & 4.01 & 4.12 & 81.58 & 46.4 & 86.1 & 4.29 & 4.14 & 86.1 & 45.1 & 89.3 \\
\hline Glycerin & 4.01 & 3.54 & 63.4 & 41.7 & 75.0 & 4.11 & 3.64 & 66.1 & 41.1 & 74.2 \\
\hline Arabic gum & 3.83 & 3.49 & 61.6 & 44.0 & 81.2 & 4.01 & 3.60 & 70.1 & 41.7 & 84.1 \\
\hline Molasses & 3.73 & 3.73 & 65.5 & 41.1 & 69.9 & 3.92 & 3.67 & 58.0 & 41.2 & 69.9 \\
\hline Urea & 4.20 & 3.92 & 86.0 & 42.0 & 71.3 & 5.46 & 3.77 & 71.2 & 53.2 & 71.3 \\
\hline Rixi film & 4.48 & 4.12 & 75.0 & 47.0 & 88.5 & 4.39 & 4.33 & 81.6 & 53.1 & 90.2 \\
\hline Adjmix-D1 & 4.25 & 4.48 & 83.8 & 48.3 & 86.6 & 4.53 & 4.19 & 79.2 & 47.5 & 86.7 \\
\hline Adjmix-D2 & 4.01 & 4.07 & 76.2 & 41.1 & 82.2 & 4.15 & 4.01 & 75.9 & 45.7 & 81.2 \\
\hline Mean-IFF & 4.03 & 3.90 & 75.0 & 43.6 & 80.1 & 4.37 & 3.89 & 73.7 & 45.6 & 80.9 \\
\hline Relative to UIFF & 103 & 111 & 140 & 127 & 132 & 111 & 109 & 134 & 121 & 127 \\
\hline Relative to P. water & 120 & 127 & 169 & 160 & 150 & 131 & 121 & 163 & 157 & 157 \\
\hline $\mathrm{LSD}_{0.05}$ & 0.25 & 0.6 & 28.0 & 11.9 & 21.0 & 0.35 & 0.45 & 24.0 & 9.0 & 22.0 \\
\hline
\end{tabular}


Table 10. Nutrient contents in white eggplant and cucumber leaves as affected by different adjuvant treatments used for improving foliar fertilizer and relative values (RV) to $\mathrm{UIFF}=100$

\begin{tabular}{|c|c|c|c|c|c|c|c|c|c|c|}
\hline \multirow{3}{*}{$\begin{array}{c}\text { Adjuvant } \\
\text { treatments }\end{array}$} & \multicolumn{5}{|c|}{$\begin{array}{l}\text { Nutrient contents in white } \\
\text { eggplant leaves }\end{array}$} & \multicolumn{5}{|c|}{$\begin{array}{l}\text { Nutrient Contents in } \\
\text { Cucumber leaves }\end{array}$} \\
\hline & $\mathbf{N}$ & $\mathbf{K}$ & $\mathbf{F e}$ & $\mathbf{Z n}$ & Mn & $\mathbf{N}$ & $\mathbf{K}$ & $\mathrm{Fe}$ & $\mathbf{Z n}$ & Mn \\
\hline & \multicolumn{2}{|c|}{$\%$} & \multicolumn{3}{|c|}{ ppm } & \multicolumn{2}{|c|}{$\%$} & \multicolumn{3}{|c|}{ ppm } \\
\hline Pure water & 4.12 & 3.61 & 111 & 25.7 & 141 & 3.15 & 2.95 & 44.5 & 27.5 & 53.0 \\
\hline$\%$ & 96 & 93 & 92 & 85 & 86 & 84 & 89 & 84 & 78 & 86 \\
\hline UIFF & 4.30 & 3.86 & 121.0 & 30.3 & 164 & 3.75 & 3.30 & 52.8 & 35.1 & 61.6 \\
\hline $\mathrm{RV} \%$ & 100 & 100 & 100 & 100 & 100 & 100 & 100 & 100 & 100 & 100 \\
\hline TEA & 4.75 & 4.45 & 136 & 37.3 & 197 & 4.42 & 3.64 & 76.6 & 45.8 & 87.8 \\
\hline $\mathrm{RV} \%$ & 110 & 115 & 113 & 123 & 120 & 118 & 110 & 145 & 130 & 143 \\
\hline Liquid soap & 4.95 & 4.54 & 140 & 37.5 & 200 & 4.10 & 3.78 & 79.8 & 46.0 & 86.4 \\
\hline $\mathrm{RV} \%$ & 115 & 117 & 116 & 124 & 122 & 109 & 114 & 151 & 131 & 140 \\
\hline Glycerin & 4.65 & 4.34 & 130 & 32.4 & 188 & 3.89 & 3.55 & 61.8 & 40.5 & 73.7 \\
\hline RV \% & 108 & 112 & 108 & 107 & 115 & 104 & 107 & 117 & 115 & 120 \\
\hline Arabic gum & 4.64 & 4.38 & 132 & 33.4 & 186 & 3.83 & 3.41 & 59.7 & 42.1 & 79.8 \\
\hline $\mathrm{RV} \%$ & 108 & 113 & 109 & 110 & 113 & 102 & 103 & 113 & 120 & 130 \\
\hline Molasses & 4.48 & 4.23 & 127 & 29.8 & 177 & 3.77 & 3.47 & 55.1 & 39.4 & 69.9 \\
\hline $\mathrm{RV} \%$ & 104 & 110 & 105 & 98 & 108 & 101 & 105 & 104 & 112 & 113 \\
\hline Urea & 4.62 & 4.38 & 132 & 32.9 & 183 & 4.45 & 3.57 & 64.5 & 38.9 & 71.3 \\
\hline $\mathrm{RV} \%$ & 107 & 113 & 109 & 108 & 112 & 119 & 108 & 122 & 111 & 116 \\
\hline Rixi film & 4.93 & 4.58 & 140 & 37.4 & 200 & 4.17 & 3.86 & 76.9 & 48.0 & 86.6 \\
\hline RV \% & 115 & 119 & 116 & 123 & 122 & 111 & 117 & 146 & 137 & 141 \\
\hline Adjmix-D1 & 5.32 & 4.60 & 143 & 38.4 & 211 & 4.35 & 3.95 & 77.3 & 49.3 & 84.3 \\
\hline $\mathrm{RV} \%$ & 124 & 119 & 118 & 126 & 129 & 116 & 120 & 146 & 141 & 137 \\
\hline Adjmix-D2 & 5.16 & 4.52 & 141 & 37.3 & 208 & 3.89 & 3.63 & 72.3 & 41.8 & 80.3 \\
\hline $\mathrm{RV} \%$ & 120 & 117 & 116 & 123 & 127 & 104 & 110 & 137 & 119 & 130 \\
\hline Mean - IFF & 4.83 & 4.45 & 136 & 35.1 & 195 & 4.10 & 3.67 & 70.2 & 44.2 & 80.4 \\
\hline Relative to UIFF & 112 & 115 & 112 & 116 & 119 & 110 & 111 & 133 & 126 & 131 \\
\hline Relative to pure water & 117 & 123 & 122 & 134 & 138 & 130 & 124 & 158 & 161 & 152 \\
\hline $\mathrm{LSD}_{0.05}$ & 0.30 & 0.5 & 10.1 & 3.2 & 22.7 & 0.32 & 24.8 & 12.5 & 5.4 & 8.5 \\
\hline$\%$ & 7.0 & 13.0 & 8.3 & 10.6 & 13.8 & 8.5 & 7.6 & 23.7 & 15.5 & 13.8 \\
\hline
\end{tabular}

liquid soap and TEA that give the highest relative increases in $\mathrm{Fe}, \mathrm{Zn}$, and $\mathrm{Mn}$ contents. For white eggplant, these increases were about $143 \mathrm{ppm}$ (118), 141 (116), 140 (116), 140 (116) and 136 ppm (113\%) for Fe, 38.4 (126), 37.3 (123), 37.4 (123), 37.5 (124) and $37.3 \mathrm{ppm}(123 \%)$ for $\mathrm{Zn}$ and 211 (129), 208 (127), 200 (122), 200 (122) and $197 \mathrm{ppm}(120 \%)$ for $\mathrm{Mn}$, respectively compared with that of UIFF $=100$. These results illustrated the higher positive effect of surfactants (i.e., TEA and liquid soap) as adjuvants on spreading rate of the improved foliar fertilizer (IFF) on leaves leading to increase nutrient uptake as illustrated by Czarnota and Thomas (2014).
For cucumber, the increases were about 77.3 (146), 72.3 (137), 76.9 (146), 79.8 (151), and $76.6 \mathrm{ppm}$ (137\%) for Fe, 49.3 (141), 41.8 (119), 48.0 (137), 46.0 (131) and $45.8 \mathrm{ppm}(130 \%)$ for $\mathrm{Zn}$ and 84.3 (137), 80.3 (130), 86.6 (141), 86.4 (140), and $87.8 \mathrm{ppm}$ (143\%) for Mn by using Adjmix-D1, Adjmix-D2, Rixi film, liquid soap and TEA for improving foliar fertilizers, respectively.

These results illustrated the higher positive effect of surfactants (i.e., TEA and liquid soap) as adjuvants on spreading rate of the IFF on leaves leading to increase the efficiency of nutrient uptake as declared by Czarnota and Thomas (2014). 
The average and relative increases in $\mathrm{N}, \mathrm{K}, \mathrm{Fe}$, $\mathrm{Zn}$ and Mn contents as affected by the tested adjuvants each alone or in combination in four sequence applications were about $4.83 \%$ (112), 4.45\% (115), 136 ppm (112), 35.1 ppm (116\%) and $195 \mathrm{ppm}$ (119\%) for white eggplant leaves respectively relative to that of $\mathrm{UIFF}=100$ (Table 10). The increase in $\mathrm{N}, \mathrm{K}, \mathrm{Fe}, \mathrm{Zn}$ and Mn contents reached to about $117,123,122,134$ and $138 \%$ for white eggplant and 130, 124, 158, 161 and 152\% for cucumber respectively relative to that of pure water $=100$

(Table 10). However, these increases more pronounced for cucumber than white eggplant. This may be attributed to the differences in the roughness properties of plant leaves (De Ruiter et al 1995).

It is worthy to mention that the highest increase in $\mathrm{N}, \mathrm{K}, \mathrm{Fe}, \mathrm{Zn}$ and Mn contents in white eggplant leaves as affected by the IFF applied in four sequence weekly applications were obtained by using Adjmix-D1 in improving the foliar fertilizers (Table 10). These increases were about 5.32\% (124), 4.6\% (119), 143 ppm (118), 38.4 ppm (126) and $211 \mathrm{ppm}(129 \%)$ for white eggplant and 5.35, (116), 3.95\% (120\%), $77.3 \mathrm{ppm}$ (146), $49.3 \mathrm{ppm}$ (141) and $84.3 \mathrm{ppm}$ (137\%) for cucumber, respectively Table 10. The highly positive effect of Adjmix-D1 to improve foliar fertilizers can be due to the combined effect of its adjuvants components in increasing spreading rate, sticking, humectant, penetrating which together act to increase the efficiency of plant utilization of IFF.

However, surfactants such as TEA, and liquid soap and sticker such as Arabic gum, and molasses often added to adjuvants to improve spreading and sticking of the fertilizer on the leaf surface and increase the area of leaf interacting with the fertilizer (Fernández and Eichert 2009).

In addition to the ability of foliar sprays to spread and stick to leaves is essential to enable uptake of nutrients. Many plant species including cucumber have been shown to have low wettability due to leaf surface roughness which caused by waxes and hairs (De Ruiter et al 1995).

\subsection{Effects of the improved foliar fertilizers (IFF) on fruit crop yields}

To evaluate the efficiency of using the suggested adjuvants (each alone or in combination) for improving foliar fertilizers, two field experi- ments were carried out by spraying white eggplants and cucumber crops in sequence weekly applications to evaluate its efficiency on fruit yield and nutrient contents.

Data in Table 11 show the average effect of the IFF by using the different adjuvants treatments on the fruit yield of eggplants and cucumber relative to pure water treatment $=100$ or relative to $\mathrm{UIFF}=100$.

In general, the obtained results revealed that the IFF increased fruit yield by $23 \%$ relative to pure water treatment $=100$ and $8 \%$ relative to UIFF treatment $=100$. These results demonstrated the importance of foliar fertilizers application and the IFF for increasing fruit yield.

Data in Table 11 show the average fruit yield as affected by the IFF using the different suggested adjuvants relative to $\mathrm{UIFF}=100$. Data indicated that the highest increase in fruit yield of the tested crops observed at the application of the improved foliar fertilizer using Adjmix-D1. This increase was about $42 \%$ relative to pure water treatment $=100$ or $27 \%$ relative to UIFF treatment $=100$.

It could be also observed that application of molasses treatment for improving foliar fertilizer caused a reduction in fruit yield to about $87 \%$ relative to $\mathrm{UIFF}=100$. This reduction may be ascribed to the possible adverse effects of some additives to molasses such as sulfur dioxide (sulfured molasses), which acts as a preservative, preventing the molasses from spoiling (El-Geddawy et al 2012 and McDonell 2020).

Table 11. Average effects of IFF using the different suggested adjuvants on relative fruit yield to pure water $=100$ or relative to $\mathrm{UIFF}=100$

\begin{tabular}{|c|c|c|c|c|}
\hline \multirow{2}{*}{$\begin{array}{c}\text { Adjuvant } \\
\text { treatments }\end{array}$} & \multicolumn{3}{|c|}{$\begin{array}{c}\text { Crop yield Relative to pure } \\
\text { water or UIFF=100- \% }\end{array}$} \\
\cline { 2 - 5 } & White eggplants & \multicolumn{2}{c|}{ Cucumber } \\
\hline Pure water & 85 & 100 & 92 & 100 \\
\hline UIFF & 100 & 118 & 100 & 109 \\
\hline TEA & 113 & 134 & 102 & 111 \\
\hline Liquid soap & 123 & 145 & 116 & 127 \\
\hline Glycerin & 108 & 127 & 100 & 109 \\
\hline Arabic gum & 107 & 127 & 97 & 106 \\
\hline Molasses & 81 & 96 & 92 & 100 \\
\hline Urea & 109 & 129 & 102 & 111 \\
\hline Rixi film & 119 & 141 & 110 & 120 \\
\hline Adjmix-D1 & 128 & 151 & 129 & 140 \\
\hline Adjmix-D2 & 114 & 135 & 110 & 120 \\
\hline Mean & 110 & 130 & 106 & 116 \\
\hline
\end{tabular}


Data in Table 12 show the fruit yield of white eggplants as affected by adjuvants treatments used for improving foliar fertilizers during four sequence applications. Data indicated that the highest increase in fruit yield of eggplants was obtained with the application of adjmix-D1 followed by adjmix-D2. These increases were about 28 and $14 \%$, respectively.

Results indicated that the fruit yield of white eggplants as affected by application of the improved foliar fertilizer treatment could be arranged in the following descending order: Adjmix-D1 > Liquid soap > Rixi film > AdjmixD2. Similar results were also obtained for the four sequence fruit harvestings each after 7 days from the application of pure water, IFF and UIFF treatments. No substantial changes in fruit weight in $\mathrm{g} /$ fruit were observed for all the tested treatments. Similar findings were obtained by Gaskin and Stevens (1993); Gaskin et al (2000), and Czarnota and Thomas (2014).
Data in Table 13 show the fruit yield of cucumber as affected by adjuvants treatments used for improving foliar fertilizers during the sequence applications. Data indicated that the highest increase in fruit yield of cucumber obtained with the application of Adjmix-D1 followed by adjmix-D2. These increases were about 29 and $10 \%$, respectively.

Data in Table 13 indicated that the fruit yield of cucumber influenced by the application of the improved Foliar fertilizer treatment could be arranged in the following descending order: Adjmix-D1>Liquid soap>Adjmix-D2 = Rixi film. Similar results were also obtained for the four sequences fruit harvestings each after 7 days from the application of pure water, IFF and UIFF treatment.

These results may be attributed to the effect of these adjuvants in enhancing the wettability of plant leaves with the IFF and in consequently increase nutrient uptake. These results are in agreement with that obtained by Alexander and Schroeder (1987), Brazee and Zhu (2004) and Fernández and Brown (2013) and. No substantial changes in fruit weight in $\mathrm{g} /$ fruit were observed for all the tested treatments.

Table 12. Fruit yield of white eggplants as affected by adjuvants treatments used for improving foliar fertilizers during four sequence applications

\begin{tabular}{|c|c|c|c|c|c|c|c|c|}
\hline \multirow{2}{*}{$\begin{array}{l}\text { Adjuvant } \\
\text { Treatments }\end{array}$} & \multirow{2}{*}{$\begin{array}{c}\text { Mean } \\
\text { Fruit No. } \\
\text { Fruit/plant }\end{array}$} & \multicolumn{4}{|c|}{$\begin{array}{c}\text { White eggplants fruit yield in g/plant } \\
\text { at } 4 \text { sequence harvestings }\end{array}$} & \multicolumn{2}{|c|}{$\begin{array}{c}\text { Mean } \\
\text { Fruit yield }\end{array}$} & \multirow{2}{*}{$\begin{array}{c}\text { Relative } \\
\text { Fruit yield } \\
\%\end{array}$} \\
\hline & & $21-5-20$ & $28-5-20$ & 4-6-20 & 11-6-20 & g/fruit & g/plant & \\
\hline Pure water & 4.80 & 74 & 142 & 205 & 211 & 32.9 & 158 & 85 \\
\hline UIFF & 5.61 & 116 & 152 & 223 & 257 & 33.4 & 187 & 100 \\
\hline TEA & 6.27 & 123 & 184 & 261 & 277 & 33.7 & 211 & 113 \\
\hline Liquid soap & 6.88 & 131 & 184 & 263 & 341 & 33.4 & 230 & 123 \\
\hline Glycerin & 6.02 & 120 & 154 & 251 & 280 & 33.5 & 201 & 108 \\
\hline Arabic gum & 5.92 & 118 & 174 & 248 & 262 & 33.9 & 201 & 107 \\
\hline Molasses & 4.57 & 70.6 & 135 & 194 & 209 & 33.3 & 152 & 81 \\
\hline Urea & 6.02 & 124 & 185 & 249 & 257 & 33.8 & 204 & 109 \\
\hline Rixi film & 6.57 & 121 & 163 & 267 & 338 & 33.9 & 222 & 119 \\
\hline Adjmix-D1 & 7.55 & 163 & 204 & 299 & 355 & 33.8 & 255 & 136 \\
\hline Adjmix-D2 & 7.08 & 144 & 176 & 300 & 338 & 33.8 & 239 & 128 \\
\hline Mean & 6.12 & 118 & 169 & 251 & 284 & 33.6 & 206 & 114 \\
\hline $\mathrm{LSD}_{0.05}$ & 0.9 & 4.0 & 20.5 & 37.0 & 20.0 & 1.1 & 24.0 & 12.8 \\
\hline
\end{tabular}


Table 13. Cucumber fruit yield as affected by different adjuvants used for improving foliar fertilizers for four sequences applications

\begin{tabular}{|c|c|c|c|c|c|c|c|c|}
\hline \multirow{2}{*}{$\begin{array}{c}\text { Adjuvant } \\
\text { Treatments }\end{array}$} & \multirow{2}{*}{$\begin{array}{c}\text { Mean } \\
\text { Fruit No. } \\
\text { Fruit/plant }\end{array}$} & \multicolumn{4}{|c|}{$\begin{array}{l}\text { Cucumber fruit yield in g/plant } \\
\text { at } 4 \text { sequence harvestings }\end{array}$} & \multicolumn{2}{|c|}{$\begin{array}{c}\text { Mean } \\
\text { Fruit yield }\end{array}$} & \multirow{2}{*}{$\begin{array}{c}\text { Relative } \\
\text { Fruit yield } \\
\% \\
\end{array}$} \\
\hline & & 11-10-20 & 18-10-20 & $25-10-20$ & 1-11-20 & g/fruit & g/plant & \\
\hline Pure water & 1.23 & 73.0 & 125 & 132 & 173 & 102 & 502 & 92 \\
\hline UIFF & 1.33 & 77.2 & 140 & 149 & 181 & 103 & 547 & 100 \\
\hline TEA & 1.37 & 77.1 & 132 & 157 & 194 & 102 & 559 & 102 \\
\hline Liquid soap & 1.57 & 102 & 138 & 187 & 209 & 101 & 636 & 116 \\
\hline Glycerin & 1.35 & 76.6 & 127 & 135 & 209 & 101 & 548 & 100 \\
\hline Arabic gum & 1.35 & 50.4 & 141 & 127 & 213 & 98 & 531 & 97 \\
\hline Molasses & 1.27 & 90.2 & 114 & 126 & 174 & 99 & 504 & 92 \\
\hline Urea & 1.37 & 97.2 & 143 & 128 & 189 & 102 & 557 & 102 \\
\hline Rixi film & 1.45 & 98.3 & 145 & 142 & 216 & 104 & 601 & 110 \\
\hline Adjmix-D1 & 1.70 & 110 & 169 & 197 & 229 & 104 & 704 & 129 \\
\hline Adjmix-D2 & 1.45 & 51.2 & 155 & 174 & 221 & 104 & 601 & 110 \\
\hline Mean & 1.42 & 83.4 & 140 & 153 & 203 & 102 & 579 & 108 \\
\hline $\mathrm{LSD}_{0.05}$ & 0.20 & 15.0 & 8.0 & 15.0 & 20.1 & 0.4 & 33.0 & 6.0 \\
\hline
\end{tabular}

\section{Conclusion}

From the aforementioned results, it could be concluded that the Adjmix-D1 contained $0.6 \mathrm{~g} / \mathrm{L}$ TEA and $0.6 \mathrm{~g} / \mathrm{L}$ liquid soap as surfactants, $0.6 \mathrm{~g} / \mathrm{L}$ glycerin as a humectant, $0.6 \mathrm{~g} / \mathrm{L}$ Arabic gum as a sticker and $0.6 \mathrm{~g} / \mathrm{L}$ urea as a penetrator can be used as an effective adjuvant for improving foliar fertilizers application and use efficiency.

\section{References}

Alexander A, Schroeder M (1987) Modern trends in foliar fertilization. Journal of Plant Nutrition 10, 1391-1399.

DOI:10.1080/01904168709363671

Benton JJ (2001) Laboratory Guide for Conducting Soil Test and Plant Analysis. CRC Press, Boca Raton London, New York Washington, DC. https://doi.org/10.1201/9781420025293

Brazee RD, Bukovac MJ, Zhu H (2004) Diffusion model for plant cuticular penetration by sprayapplied weak organic acid bioregulator in presence or absence of ammonium nitrate. American Society of Agricultural and Biological Engineers 47, 629-635. DOI:10.13031/2013.16092

Chen H, Muros-Cobos JL, Amirfazli A (2018) Contact angle measurement with a smartphone. Review of Scientific Instruments 89, 035117. https://doi.org/10.1063/1.5022370
Congreve M (2019) Oils, Surfactants and other additives for farm chemicals used in grain production. Grains Research and Development Corporation. Project Code: ICN00023.

Czarnota M, Thomas P (2014) Using surfactants, wetting agents, and adjuvants in the greenhouse. University of Georgia Cooperative Extension, Athens, Georgia B-1319.

De Assunção HHT, Campos SFB, Sousa LA, Lemes EM, Zandonadi CHS, Da Cunha JPAR (2019) Adjuvants plus phytosanitary products and the effect on the physical-chemical properties of the spray liquids. Bioscience Journal, Uberlândia, 35, 1878-1885.

https://doi.org/10.14393/BJ-v35n6a2019-46994

De Ruiter HD, Straatman, KR, Meinen E (1995) Influence of two fatty amine surfactants on foliar absorption, translocation, and efficacy of 2,4-D Triethanolamine salt. Journal of Agricultural and Food Chemistry. 43, 3093-3097.

https://pubs.acs.org/doi/pdf/10.1021/jf00060a018

Dordas C (2009) Role of nutrients in controlling plant diseases in sustainable agriculture: a review. In: $\mathrm{E}$. Lichtfouse et al (Eds.), Sustainable Agriculture. Springer, Dordrecht.

https://doi.org/10.1007/978-90-481-2666-8_28

El-Geddawy Mennat-Allah MA, Omar MB, Magda MS, Seleim M, Elsyiad SI (2012) Composition and properties of Egyptian beet molasses. Journal of Food and Dairy Sciences, Mansoura Univ, 3, 669-679. 
https://jfds.journals.ekb.eg/article_81735_ad55d7 673e6151607caf88a5523f7c7d.pdf

Fernández V, Eichert T (2009) Uptake of hydrophilic solutes through plant leaves: Current state of knowledge and perspectives of foliar fertilization. Critical Reviews in Plant Sciences. 28, 3668. https://doi.org/10.1080/07352680902743069

Fernández V, Brown PH (2013) From plant surface to plant metabolism: the uncertain fate of foliar-applied nutrients. Frontiers in Plant Science, 4, 289.

https://doi.org/10.3389/fpls.2013.00289

Gaskin RE, Steele KD, Forster WA (2005) Characterizing plant surface for spray adhesion and retention. New Zealand Plant Protection, 58,179183. https://doi.org/10.30843/nzpp.2005.58.4244

Gaskin RE, Murray RJ, Krishna, H, Carpenter A (2000) Effect of adjuvants on the retention of insecticide spray on cucumber and pea foliage. Proceedings of the New Zealand plant protection conference, pp 355-359.

https://doi.org/10.30843/nzpp.2000.53.3608

Gaskin RE, Stevens PJG (1993) Antagonism of the foliar uptake of glyphosate into grasses by organosilicone surfactants. Part 2: Effects of surfactant structure and glycerol addition. Peat management Science, 38, 193-200.

https://doi.org/10.1002/ps.2780380214

Gooding MJ, Davies WP (1992) Foliar urea fertilization of cereals - a review. Fertilizer Research, 32, 209-222. DOI:10.1007/bf01048783

Harkins WD, Brown FE (2019) The determination of surface tension and the weight of falling drops: The surface tension of water and benzene by the capillary height method, Journal of the American Chemical Society, 41, 499.

https://pubs.acs.org/doi/pdf/10.1021/ja01461a003

Lamour G, Hamraoui A (2010) Contact Angle Measurements Using a Simplified Experimental Setup. Journal of Chemical Education, 87, 14031407. https://doi.org/10.1021/ed100468u

Martin JT, Juniper BE (1970) The cuticles of plants. Edinburgh, UK.

McDonell K (2020) Everything you need to know about molasses. Medical News Today, 16 March 2020.

https://www.medicalnewstoday.com/articles/3187 $\underline{19}$
Nairn JJ, Forster WA, Van Leeuwen RM (2013) Universal spray droplet adhesion model - accounting for hairy leaves. Weed Research, 53, 407-417.

https://onlinelibrary.wiley.com/doi/epdf/10.1111/wre. $\underline{12039}$

Oosterhuis DM, Weir BL (2010) Foliar fertilization of Cotton. In: Stewart J.M., Oosterhuis DM, Heitholt JJ, Mauney JR (Eds) Physiology of Cotton. Springer, Dordrecht.

https://doi.org/10.1007/978-90-481-3195-2_25

Ortiz PR, Meza BIC, Requena FRdlG, Flores GM, Barra JDE (2007) Evaluation of different iron compounds in chlorotic Italian lemon trees (Citrus lemon) Plant Physiology and Biochemistry - Journals. 45, 330-334. DOI:10.1016/j.plaphy.2007.03.015

Park SY, Hannemann RE, Franse EI (1999) Dynamic tension and adsorption behavior of aqueous lung surfactants. Colloids and Surfaces B: Biointerfaces, 15, 325-338.

Penner D (2000) Activator adjuvants. Weed Technology, 14, 785-791.

https://doi.org/10.1614/0890037X(2000)014[0785:AA]2.0.CO;2

Prado EP, Raetano CG, Dal Pogetto MHF, Chechetto RG, Filho PJF, Magalhães AC, Miasaki CT (2016) Effects of agricultural spray adjuvants in surface tension reduction and spray retention on Eucalyptus leaves. African Journal of Agricultural Research, 11, 3959-3965. DOI:10.5897/AJAR2016.11349

Price CE (1982) A review of factors influencing the penetration of pesticides through plant leaves. in Cutler DF, Alvin KL, Price DE (Ed.) "The Plant Cuticle". Academic Press, London. Linnean Society Symposium Series No. 10, 237-252.

http://www.globalsciencebooks.info > EJPSB 1(1)

Rosen M, Kunjappu JT (1989) Surfactants and Interfacial Phenomena, $\left(4^{\text {Th }}\right.$ Ed.) Wiley, New York, NY, US. pp 235-271.

https://download.e-

bookshelf.de/download/0000/5942/86/L-G0000594286-0002364626.pdf

Rasmussen HR (2016) Foliar application of iron chelated fertilizer and surfactants for management of iron deficiency chlorosis in soybeans. MSc._Thesis, North Dakota State University of Agriculture and Applied Science. 
Santos RTS, Ferreira MC, Viana RG (2019) Does the use of adjuvants alter surface tension and contact angle of herbicide spray droplets on leaves of Sida Spp.? Planta Daninha, 37, e019185603. DOI:10.1590/s0100-83582019370100082

Smoleń S (2012) Foliar Nutrition: Current State of Knowledge and Opportunities. In: Srivastava A. (Eds) Advances in Citrus Nutrition. Springer, Dordrecht.

https://doi.org/10.1007/978-94-007-4171-3_4
Soni M (2019) A simple laboratory experiment to measure the surface tension of a liquid in contact with air. Journal of Pharmacognosy and Phytochemistry, 8, 2197-2202.

Tu M, Randall J (2003) Adjuvants. Weed Control Methods Handbook, The nature Conservancy, Utah State University. 8, 1-24.

https://www.invasive.org/gist/products/handbook/21. $\underline{\text { Adjuvants.pdf }}$ 